\title{
UCLA
}

Mester

Title

NOTES ON EDITORS AND CONTRIBUTORS

Permalink

https://escholarship.org/uc/item/3z8456hq

Journal

Mester, 49(1)

Author

Galindo, Barbara

Publication Date

2020

DOI

10.5070/M3491051398

Copyright Information

Copyright 2020 by the author(s). All rights reserved unless otherwise indicated. Contact the author(s) for any necessary permissions. Learn more at https://escholarship.org/terms

Peer reviewed 


\section{Notes on Editors and Contributors}

\section{APFFEL-MARGLIN, FRÉDÉRIQUE}

Professor Emerita, Department of Anthropology at Smith College. Founder of Sachamama Center for Biocultural Regeneration in the Peruvian Upper Amazon in 2009, which she directs. She spent years in India and Peru working with indigenous peoples and local farmers. For several years throughout the 80s and early 90s, she was a research associate at the World Institute for Development Economics Research (WIDER) in Helsinki, a part of the United Nations University. Along with Harvard economist Stephen A. Marglin, she has directed several research projects questioning the dominance of the modern paradigm of knowledge. She has authored as well as edited fifteen books, and published some 70 articles. In 1993, she decided for political and ethical reasons that she could no longer engage in classical anthropological fieldwork, and ever since then has been invited to collaborate with activist/intellectual groups in Peru and Bolivia. She recently brought out Subversive Spiritualities: How Rituals Enact the World (oxford U. Pr. 2011). Her latest book, edited with Stefano Varese is Contemporary Voices from Anima Mundi, Peter Land Academic Pr. 2020.

\section{ARAÚJO, JASON}

PhD student in the Department of Comparative Literature at UCLA.

\section{BACHMANN, THERESA $\mathrm{K}$.}

Doutora em Literatura Latino-americana pela Universidade da Califórnia, Davis. Atualmente, trabalha como professora substituta no Departamento de Letras da Universidade Federal de Pernambuco (Recife, Brasil), mesma instituição pela qual realizou estudos de mestrado na área de Teoria da Literatura. É formada em Comunicação Social/Jornalismo pela Universidade Católica de Pernambuco, e licenciada em Letras Português/Espanhol pela Universidade Federal de Pernambuco. Suas áreas de interesse são os estudos de memória, literatura e exílio, e produção cultural de/sobre imigrantes no México nos séculos XX e XXI. 


\section{BIVONA, KRISTAL}

Assistant Director of the Behner Stiefel Center for Brazilian Studies at San Diego State University, where she also teaches. Her current research project examines how filmmakers grapple with the memory of the dictatorship and transitional justice in Brazil and the Southern Cone. She holds a Ph.D. in Hispanic Languages and Literatures from UCLA.

\section{BURT, BENJAMIN}

Assistant Adjunct Professor in the UCLA Department of Spanish and Portuguese and Research Fellow at the UCLA Center for Brazilian Studies. His research bridges utopian studies, urban cultural studies, and ecocriticism. His dissertation, "Cities of Dreams and Despair: Utopia and Dystopia in Contemporary Brazilian Film and Literature" (2020), explores utopian thinking in post-dictatorship, urban Brazil. His current project explores modernity, memory, and urban development in Brazil, Cuba, and Mexico through the lens of literature and cinema.

\section{CHIRIF, ALBERTO}

Antropólogo de la Universidad Nacional Mayor de San Marcos. Trabaja en la Amazonía desde hace cincuenta años, en temas vinculados con los derechos colectivos de los pueblos indígenas. Es autor de numerosos artículos especializados y de libros colectivos, como "El Indígena y su Territorio (1991)" y "Marcando Territorio. Progresos y limitaciones de la titulación de territorios indígenas en la Amazonía (2007)"; e individuales: "Pueblos de la yuca brava (2014)", "Diccionario Amazónico" (2015) y "Después del caucho (2017).

\section{CLAUDIO, ESTHER}

Ph.D. candidate at the University of California, Los Angeles. Her research interests revolve around comics in two directions: the formal study of experimental works, and the study of memory as a mechanism of transitional justice. Feminism, urban studies, and social justice permeate all her writings. She has presented her work at several international conferences, and she was the coordinator and organizer of the First International Conference of Comics and Graphic Novels in Spain (November 9-12, 2011, Universidad de Alcalá). She is co-editor of On the Edge of the Panel: Essays on Comics Criticism (Cambridge Scholars Publishing, 2015), as well as co-founder and co-editor of www.comicsgrid.com, a pioneering academic website devoted to 
comicbook scholarship. She is currently member of the editorial team of the academic journals Mester (University of California, Los Ángeles) and CuCo: Cuadernos de cómic.

\section{DE ASSIS FERNANDES GONÇALVES, RICARDO JUNIOR}

Possui Pós-Doutorado em Geografia pela Universidade Federal de Juiz de Fora (UFJF), Mestrado e Doutorado em Geografia pela Universidade Federal de Goiás (UFG). Professor nos cursos de Graduação e Pós-Graduação Stricto-Sensu em Geografia da Universidade Estadual de Goiás (UEG). Pesquisador do Grupo de Pesquisa e Extensão "Política, Economia, Mineração, Ambiente e Sociedade" (PoEMAS).

\section{DE LA TORRE AMAGUANA, LUZ MARIA}

Lecturer at the Department of Spanish and Portuguese and the Latin American Institute at UCLA. She is a Kichwa (Quechua) indigenous woman from Ecuador. She received her B.A. in Languages and Applied Linguistics from the Catholic University of Ecuador (1997). Her thesis focused on Indigenous Bilingual Education. She earned her Master's degree in Political Sciences at FLACSO (2006). Her research focused on the Indigenous Movement, and the relationship with the Ecuadorian government in the 1990s, when the Indigenous National uprising took place. She has taught at the numerous universities in Ecuador and the U.S., including Arizona State University and Middlebury College. She worked in the Ministries of Education and Foreign Relations, where she served both as Ambassador in charge, and Consul. She has worked as a consultant for a wide range of national and international institutions and NGOs. She has lectured frequently in Ecuador and many other countries. Her research, writing, and teaching focus on topics related to Kichwa/Quechua and Spanish, Andean Indigenous cosmovision, gender from the Andean perspective, Andean alternative economies and knowledge, and new political relations between the nation-state and indigenous peoples. Currently, her latest book proposal deals with a collection of Kichwa poems translated into Spanish, and English. "What does it mean to be an Indigenous woman today?". Additionally, she is developing a Manual for teaching the Quechua/Kichwa language.

\section{DELGADO-P., GUILLERMO}

Obtuvo el doctorado en Antropología en la Univ. de Texas (Austin). Es Licenciado por la Univ. Católica de Chile (Santiago). Es profesor 
en el Departamento de Antropología, Universidad de California Santa Cruz, donde es también director de Field Studies. Sus más recientes contribuciones están en Contemporary Voices from Anima Mundi (2020), y en Viewpointmag.com (2018); es co-editor de Indigeneity Collected Essays (2012); Quechua Verbal Artistry/Arte Verbal Quechua (Bonn 2004). Sirvió de editor de tres volúmenes sobre cultura minera andina: Recuerdos de Ayer (2012); Carne de Cañón, Ahora Arde Kollitas (2016), y Crónica y Memoria del Periodismo Minero (2018). Acaba de compilar una colección suya de ensayos culturales Lectores Somos (1980-2020) que esperan publicación en 2021.

\section{FELMAN-PANAGOTACOS, MADISON}

Fulbright-Hays Fellow and a doctoral candidate in Hispanic Languages \& Literatures at UCLA. Her areas of research center on the cultural production of twentieth- and twenty-first-century Mexico and Argentina, with a focus on studies of feminist social movements, maternity and non-patriarchal parenthood, and abortion rights. She has been published in A contracorriente, Imagofagia, and the LA Review of Books.

\section{GALINDO, BARBARA}

PhD candidate at the Spanish and Portuguese Department of UCLA. She specializes in Latin American literatures and cultures, with a focus on Andean and Amazonian cultural production. In 2013, she received a grant from the Brazilian National Library to do the first Spanish translation of seven essays on Amazonia by Brazilian writer Euclides da Cunha, Un paraíso perdido: ensayos amazónicos (2016), published by Pasacalle. She lived in the Peruvian Amazon where she worked on a literary cartonera project (2010-2012) directed by Dr. Frédérique Apffel-Marglin, in collaboration with the Ethnic Council of Kichwa Youth in Amazonia and as part of the international project "Cultural Agents" directed by Professor Doris Summer of the Romance Languages Department at Harvard University. She edited and published three books written by indigenous authors: the bilingual Spanish-Quechua Habla en quechua (Como la estrella) / Qichwapi rimay (Quyllurshina), and the bilingual English-Quechua Speaking in Quechua (Like the Stars) / Qichwapi rimay (Quyllurshina) (2011) by Genaro Bendezú and Felipe Cachique Amasifuén (in memoriam); the Spanish ¿Por qué no cuidar a esos montes sagrados? (2012), by Girvan Tuanama Fasabi; and the bilingual Spanish-Quechua Willakuykuna 
kawsashkankuna (2014), by Royner Sangama Sangama. She is currently writing her dissertation on the cultural representations of mining terror in the Andes from the end of the 19th century to the first half of the twentieth century. Her work aims to develop new concepts that contribute to decolonize the debate on extractivism in Latin America.

\section{GARCÍA MORENO, VERÓNICA}

Doctora en literatura española por UCLA, con una tesis sobre la influencia del elemento islámico en la formación de las identidades peninsulares durante el siglo XIX. Además, tiene una maestría en Estudios Islámicos por la Universidad de Sevilla (España) y otra maestría en Lingüística Aplicada por la Universidad de León (España). Actualmente prepara un estudio sobre el orientalista Rafael Cansino Assens, su labor de traductor e interpretador de los textos semitas, árabes y persas y su influencia en la literatura española e hispanoamericana de principios del siglo XX.

\section{GIMÉNEZ, ISAAC}

Ph.D. candidate in the Department of Spanish and Portuguese at UCLA. Originally from Badajoz, Spain, with a background in translation and interpreting studies. His research interests include Brazilian (and, more broadly, Latin American) literature and cinema. He seeks to create points of convergence between Latin American, North American, and Iberian contemporary cultures. He is currently working on a dissertation project focused on 20th and 21st Brazilian poetry.

\section{GONZÁLEZ CALDERÓN, JULIA}

Doctoranda del Departamento de Español y Portugués de la UCLA, donde también ha completado una concentración de posgrado en Estudios de Género. Es licenciada en Filología Hispánica y máster en Estudios Hispánicos Superiores por la Universidad de Sevilla, y ha trabajado como lectora de español en la Universidad de Michigan en Ann Arbor y la Universidad Delta State en Cleveland, Mississippi. Su investigación se centra en el análisis de la narrativa policial centroamericana contemporánea, producida tanto en español como en inglés, en el contexto del nuevo mercado neoliberal y la sociedad de posguerra, y le interesan los estudios de género, de la diáspora, de la memoria y de genocidio. Ha recibido becas para investigar en Costa Rica, El Salvador y Guatemala y su trabajo ha sido presentado en múltiples congresos (entre otros: FLACSO, CEISAL, IILI, MLA, 
ACLA y LASA) y publicado en diversas revistas, como Alea, Clues y, próximamente, Istmo. Es miembro del comité editorial de Mester desde 2017.

\section{HERNÁNDEZ, LEANDRO ARSENIO}

Ph.D. student in the Department of Spanish and Portuguese at UCLA. He started his academic training by studying literature in Argentina. After working for two years as a high-school teacher, he began his research career in the United States by completing a Master's degree in Spanish. He is interested in 20th-century and contemporary Latin American literature. More recently, he has been working on the representation of chronic diseases in literature and culture.

\section{HOOD, MARY}

Ph.D. student at the Spanish and Portuguese dept of UCLA. She is interested in the philosophy and politics behind Latin American dictatorships and the study of resulting issues of memory and trauma. Her research tends to focus on post-dictatorship Southern Cone literature. Lately, she has been working on articles centered on the representations of women and sexuality in post-dictatorship Argentine crime fiction.

\section{LINO, PATRÍCIA}

Assistant Professor of Luso-Brazilian Literatures and cinema at UCLA and the author of O Kit de Sobrevivencia do Descobridor Português no Mundo Anticolonial (2020), Não é isto um livro (2020), and Manoel de Barros e A Poesia Cínica (2019). She recently directed Anticorpo. A Parody of the Laughable Empire (US 2019; Brazil 2020) and Vibrant Hands (2019). She is also the author of the mixed poetry album I Who Cannot Sing (2020). Lino presented, published, and exhibited essays, poems, and illustrations in more than six countries. She was one of the Portuguese poets invited to take part in the 2020 Feria del Libro de Bogotá and in the 2020 Fiesta del Libro y la Cultura de Medellín. Her current research focuses on contemporary poetry, visual and audiovisual culture, parody and anticolonialism, and Brazilian film. She also works as a research member at the UCLA Latin American Institute and a collaborator at Instituto de Literatura Comparada Margarida Losa.

NOVOA GARZON, LUIS FERNANDO 
Sociólogo e doutor em Planejamento Urbano e Regional pelo IPPUR-UFRJ, Luis Fernando Novoa Garzon foi assessor nacional de missões da Plataforma de Direitos Humanos (DHESCA). É professor do Departamento de Ciências Sociais da Universidade Federal de Rondônia (UNIR) desde 2006, em que se notabilizou por estudos e denúncias acerca dos impactos sociais e ambientais das Hidrelétricas de Santo Antônio e Jirau e pela crítica ao modelo de financiamento de grandes projetos na Amazônia pelo BNDES. É pesquisador vinculado ao laboratório ETTERN do IPPUR/UFRJ e líder do Grupo de Pesquisa “Territorialidades e Imaginários na Amazônia”, na UNIR.

\section{PORTO, DUÍNA}

Professora do Centro de Ciências Jurídicas da Universidade Federal da Paraíba/Brasil (UFPB). Doutora em Ciências Jurídicas (UFPB Direitos Humanos e Desenvolvimento), com período sanduíche na Universidade de Lausanne (UNIL/Suíça/bolsista CAPES/PDSE) e no Centro de Estudos Sociais da Universidade de Coimbra (CES/UC/ Portugal). Mestra em Ciências Jurídicas (UFPB - Direito Econômico). Especialista em Direito Processual Civil (UNIPÊ). Graduada em Direito (Universidade Federal de Pernambuco - UFPE). Atualmente, também é aluna especial do Programa de Pós-Graduação em Letras da UFPB (PPGL/UFPB). Ex-advogada e atual pesquisadora em Direito e Literatura.

\section{PORTO, LUDMILA}

Associate Professor of Portuguese Language and Linguistics at the State University of Paraiba (UEPB), and currently research scholar at the Department of Gender Studies, University of California, Los Angeles.

\section{RUMRRIL, RÓGER}

Rumrrill is a well-known Peruvian journalist and author of more than 25 books. He is a recognized expert on Amazon themes, including drug trafficking, the biological wealth of the Amazon, and social and cultural issues of indigenous peoples in Peru and other regions of Latin America. In 1963, Rumrrill founded the cultural group Bubinzana, in Iquitos, and edited the magazines Surco and Bubinzana. His most recent publication is Amazonía, luces y sombras (Amazon, lights and shades), a collection of essays and reflections on this cultural and geographical space. 


\section{SEVERO DA SILVA, DANIELE}

Possui graduação em Ciências Sociais pela Universidade Federal de Rondônia (2013), Especialização em Sociologia e Ensino de Sociologia pelo Centro Universitário Claretiano (2016). Atuou como docente substituta do Departamento de Ciências Sociais da Universidade Federal de Rondônia. Atua como professora de Sociologia do Estado de Rondônia. Cientista Social com experiência na área de Antropologia e Sociologia, com ênfase em Etnologia Indígena, Educação, Políticas de Entorno do BNDES, Cultura e História Afro-Brasileira.

\section{SOUSA RIOS, KÊNIA}

Professora do Departamento de História e do Programa de Pósgraduação em História Social da Universidade Federal do Ceará. Coordenadora do Grupo de Pesquisa História e Meio Ambiente. Desenvolve pesquisas sobre história das secas no Brasil, história da pobreza e da fome, narrativas orais dos pobres.

\section{TREVAS FALCONE, FERNANDO}

Professor do curso de Cinema e Audiovisual da UFPB. Mestre em cinema pela Universidade de São Paulo. Autor da dissertação A Crítica da Paraíba e o Cinema Brasileiro - Anos 50-60. Co-autor do artigo "Manoel Clemente: memórias da direção de fotografia na Paraíba", publicado em Anais de Textos Completos do XXIII Encontro SOCINE [recurso eletrônico] (2020), organização editorial de Angela Freire Prysthon. Autor de "Panorama da crítica de cinema na Paraíba - A Crítica nos anos 50 e 60", publicado em Trajetória da Crítica de Cinema no Brasil (2019), organização de Paulo Henrique Silva. Autor de "Aruanda", publicado em Curtas brasileiros: 100 filmes essenciais (2019), organização de Gabriel Carneiro e Paulo Henrique Silva. Co-autor e co-organizador do livro Cinema e Memória: o Super-8 na Paraíba nas Décadas de 1970 e 1980 (2013). Coordenador do projeto "Cinema Paraibano: Memória e PreservAção" (2011-2013) www. cinepbmemoria.com.br. Membro da SOCINE - Sociedade Brasileira de Estudos de Cinema e Audiovisual

\section{VARESE, STEFANO}

Italian-Peruvian anthropologist, Professor Emeritus of Native American Studies at UC Davis and former director and founder of the Indigenous Research Center of the Americas-IRCA. His research began in the Peruvian Amazon in the mid-60s with the publication of his book Salt of the Mountain. Ashaninka Resistance and Utopia 
in Amazonia, (five Spanish language editions, one English translation and one French translation). In 1975 he left Peru for Mexico, where he was appointed principal investigator in the National Institute of Anthropology and History-INAH. He was later appointed director of the Unit of Popular Cultures and Indigenous Peoples in Vera Cruz and Oaxaca. In the late 80s he moved to California, where he taught at UC Berkeley and Stanford University. In the early 90s, Varese was hired as professor in the Department of Native American Studies. He is the author of several books, including Las minorias étnicas y la comunidad nacional (Lima, 1974); Proyectos étnicos y proyectos nacionales (México, 1983); Indígenas y educación en México (México, 1983); Pueblos indios, soberanía y globalismo (Quito 1996). With Sylvia Escárcega, he co-edited La ruta mixteca. El impacto etnopolítico de la migración transnacional de los pueblos indígenas de México (México, 2004); Witness to Sovereignty. Essays on the Indian Movement in Latin America (Copenhagen, 2006). He is also co-editor, with Frédérique Apffel-Marglin and Róger Rumrril, of Selva vida. Del extractivismo al paradigma de la regeneración (Copenhagen, México, La Habana, 2013). Bonfil y la civilización del común. Crónica de un itinerario utópico (México: UNAM, 2013).

\section{VÁZQUEZ, CRISTINA G.}

She received her Master's degree in Spanish and Portuguese from the University of California, Davis, where she worked as a copyeditor for Brújula, an interdisciplinary academic journal. She is currently pursuing a doctoral degree in Peninsular and Mexican Literature and Culture through the Spanish \& Portuguese Department at UCLA. Her research interests include the counternarrative of Sub-Saharan and Haitian immigration and identity discourse through a transatlantic approach from the Lavapiés neighborhood in Madrid, Spain, and the Little Haití neighborhood in Tijuana, México. Presently, Vázquez is starting her second year as an editor of Mester. She is also part of the 2019-2020 Urban Humanities Initiative (UHI) digital archive, where she holds a graduate certificate.

\section{WALTER, ROLAND}

Full Professor of English, Comparative Literature, and Literary Theory at the Universidade Federal de Pernambuco (UFPE), Recife, Brazil. He is the author of Magical Realism in Contemporary Chicano 
Fiction (1993), Narrative Identities: (Inter)Cultural In-Betweenness in the Americas (2003) and Afro-América: Diálogos Literários na Diáspora Negra das Américas (2009), has edited the e-book As Américas: Encruzilhadas Glocais (2007) and co-edited the books Narrações da Violência Biótica (2010) and Entre Centros e Margens: Literaturas Afrodescendentes da Diáspora (2014). He has published widely in academic journals throughout the Americas and Europe, and is the author of many book chapters on diverse aspects of InterAmerican literature. 